INTERNATIONAL JOURNAL OF ENVIRONMENT

Volume-10, Issue-1, 2020/21

ISSN 2091-2854

Received:3 Dec 2020

Revised:24 Feb 2021

Accepted:26 Feb 2021

\title{
EVALUATION OF CONTAMINATION AND ACCUMULATION OF HEAVY METALS IN THE DHALESWARI RIVER SEDIMENTS, BANGLADESH
}

\author{
Abdullah Al Mamun ${ }^{1, \dagger}$, Protima Sarker(iD) ${ }^{1,2,}{ }^{*}$, Md. Shiblur Rahaman ${ }^{1,3}$, Mohammad \\ Mahbub Kabir ${ }^{1,4}$ and Masahiro Maruo ${ }^{2}$ \\ ${ }^{1}$ Department of Environmental Science and Disaster Management, Noakhali Science and \\ Technology University, Noakhali-3814, Bangladesh. \\ ${ }^{2}$ School of Environmental Science, University of Shiga Prefecture, 2500 Hassakacho, Hikone, \\ Shiga 522-8533, Japan. \\ ${ }^{3}$ Department of Environmental and Preventive Medicine, Jichi Medical University School of \\ Medicine, 3311-1 Yakushiji, Shimotsuke, Tochigi-329-0498, Japan. \\ ${ }^{4}$ Research Cell, Noakhali Science and Technology University, Noakhali-3814, Bangladesh. \\ *Corresponding author: protima_das37@yahoo.com \\ †Authors contributed equally to the manuscript
}

\begin{abstract}
The Dhaleswari river is considered as one of the most important rivers of Bangladesh due to its geographical location and ecological services. The present study attempts to evaluate the degree of heavy metal pollution, contamination, and accumulative behavior in the sediment of the Dhaleswari river. The sediment samples were collected from fifteen different locations of the Dhaleswari river. Heavy metals were analyzed using the Flame Atomic Spectrophotometer (FAAS). The mean concentrations of $\mathrm{Zn}, \mathrm{Cu}, \mathrm{Cr}, \mathrm{Pb}$ and $\mathrm{Cd}$ were 131.9, 48.89, 43.16, 33.23 and $0.37 \mathrm{mgkg}^{-1}$, respectively. According to the United States Environmental Protection Agency (USEPA) Sediment Quality Guideline, the sediment of most of the locations were not polluted for $\mathrm{Pb}$ and $\mathrm{Cd}$. But S-11 location for $\mathrm{Cd}\left(0.8 \mathrm{mg} \mathrm{kg}^{-1}\right)$ was highly polluted. For $\mathrm{Cr}, \mathrm{Cu}$ and $\mathrm{Zn}$, maximum locations were moderately polluted. Although the geo-accumulation index (Igeo) values of Dhaleswari river sediments showed almost no severe contamination for most of the sampling locations, the pollution load index (PLI) values showed that most of the sampling sites were contaminated for all heavy metals tested. Moreover, for all measured heavy metals, the mean Contamination Factor (CF) values indicated moderate pollution, except for $\mathrm{Cr}$, which suggested low pollution. The Pearson's correlation coefficient matrix among the selected heavy metals of Dhaleswari river sediment showed no significant correlation among each other. Therefore, regular monitoring of the heavy metal concentration of the Dhaleshwari river sediment from different location is necessary to identify the sources of pollution so that proper initiative could be taken to prevent heavy metal pollution.

Keywords: Sediment Quality; Pollution Load Index; Geo-accumulation Index; Contamination Factor.
\end{abstract}

DOI: http://dx.doi.org/10.3126/ije.v10i1.38399

Copyright $@ 2021$ IJE 
This work is licensed under a CC BY-NC which permits use, distribution and reproduction in any medium provided the original work is properly cited and is not for commercial purposes

\section{Introduction}

Heavy metals are well-known environmental contaminants in numerous river systems around the world due to the fast growth of population, unplanned urbanization, and industrialization (Hossain et al., 2012; Nguyen et al., 2016; Zhao et al., 2018). As heavy metal has toxicity, bioaccumulation tendency and persistence properties (Ali et al., 2016) and the presence of heavy metal in water and sediments as well as in the food chain is a great threat for human health (Marrugo-Negrete et al., 2017). Heavy metals like Arsenic (As), Cadmium (Cd), Mercury $(\mathrm{Hg})$ and $\mathrm{Lead}(\mathrm{Pb})$ can enter the human body resulting in damage to various organs and body systems (Rahaman et al., 2020). Heavy metals cause cancer, abortion, damage of internal organs and even in some cases death also occurs due to the very high concentrations of exposure (Lee et al,. 2007). Rivers are considered the major pathway for the transportation of heavy metals (Miller et al., 2003). Harmful chemicals, including heavy metals, enter water resources as other municipal and industrial waste enters the water. The disposal of domestic waste, agricultural practices using untreated industrial effluents and the flow of sewage waste into rivers contribute to water and soil pollution. (Venugopal et al., 2009; Islam et al., 2015).

Bangladesh is a riverine country which is constituted by three main rivers known as the Ganges, the Brahmaputra and the Meghna (Paul and Haq, 2010). Rapid and unplanned industrialization on the banks of the rivers in Bangladesh has increased surface water and sediment pollution (Kabir et al., 2010; Hossain et al., 2012). Rivers surrounding the two big-city Dhaka and Chittagong such as the Buriganga, Turag, Shitalakhya, and Karnaphuli rivers are extremely polluted by hazardous heavy metals like $\mathrm{Cd}, \mathrm{Pb}$, and $\mathrm{Cr}$ (Islam et al., 2018). Dhaleswari river is one of the most important distributaries of the Jamuna river which is the habitat for different aquatic organisms (Flora and Fauna) including fishes and the vegetations in the riverbank (Ahsan et al., 2018). River sediment is an important part of the ecosystem. Due to several physical and chemical interactions like dissolution, precipitation, sorption, and complexation, heavy metal can retain in the sediment of the riverbed (Islam et al., 2015). Many researchers have found that heavy metals are easily bioaccumulated in various vegetables and foods through soil contamination (Ahmad et al., 2010; Parvin et al., 2014; Islam et al., 2016).

The Dhaleswari river is directly polluted by the tannery industry and Keraniganj BSCIC area which are located very near to the river system (Mohanta et al., 2019). Limited studies have been performed to evaluate the state of pollution of the Dhaleswari river. The most important reasons for pollution in the Dhaleswari are the 46 years old Hazaribagh tannery that relocates at Savar and Karaniganj BSCIC area (Mohanta et al., 2019). Moreover, to treat the toxic and hazardous materials, no treatment plant has yet been installed. So, the river water is prone to pollution from untreated industrial effluents, municipal wastewater, agricultural runoff, and oil spills from the river ports (Alam et al., 2006).

A very few researchers carried out their studies for some physical, chemical parameters such as $\mathrm{pH}$, Biological Oxygen Demand (BOD), Dissolve oxygen (DO), water temperature, anions $\left(\mathrm{PO}_{4}{ }^{3-}, \mathrm{SO}_{4}{ }^{2-}\right.$ and $\left.\mathrm{NO}_{3}{ }^{-}\right)$, some of the specific microorganisms including total coliform, fecal coliform and, few heavy metals of the river water (Islam et al., 2012; Real et al., 2017; Mohanta et al., 2019). But no significant scientific research concerning heavy metal pollution and 
contamination of the sediment of the Dhaleswari river has been conducted yet/so far. Mohanta et al., (2019) found that the concentration of $\mathrm{As}, \mathrm{Pb}, \mathrm{Cd}, \mathrm{Cr}$ and $\mathrm{Cu}$ in the river sediment were higher than the threshold effect level of the Environmental Protection Agency. Therefore, it is essential to inspect and regularly monitor the heavy metal pollution status of sediment of Dhaleswari river for proper environmental management. The present study focuses on the pollution status of the Dhaleswari river by assessing the level of heavy metal concentration in sediment, calculating contamination factor, Geo-accumulation index and Pollution load index.

\section{Materials and methods}

\section{Study Area}

Sediment samples were collected from both banks of the river in the Keraniganj BSCIC area in Ruhitpur and the adjacent area. A total of fifteen sites were chosen by purposive sampling method (Taherdoost, 2016).

\section{Sample Collection and Preparation}

Fifteen places of Dhaleswari river were chosen to collect the sediment sample of the river in April 2018 (Fig. 1) maintaining the standard protocol (USEPA, 2001). Sediment samples were collected from the $0-12 \mathrm{~cm}$ depth and then carried into polyethylene bags. The polyethylene bags were washed with $10 \% \mathrm{HNO}_{3}$ acid solution followed by distilled water to remove impurities. Sediment samples were preserved in an icebox during sample transportation. Then the sediment was dried in an oven at $45{ }^{\circ} \mathrm{C}$ for $48 \mathrm{~h}$ in a dust-free place, then ground into fine powder using pestle and mortar and sieved under $2 \mathrm{~mm}$ mesh. Samples were then stored in plastic containers (Jumbee and Nandini, 2009).

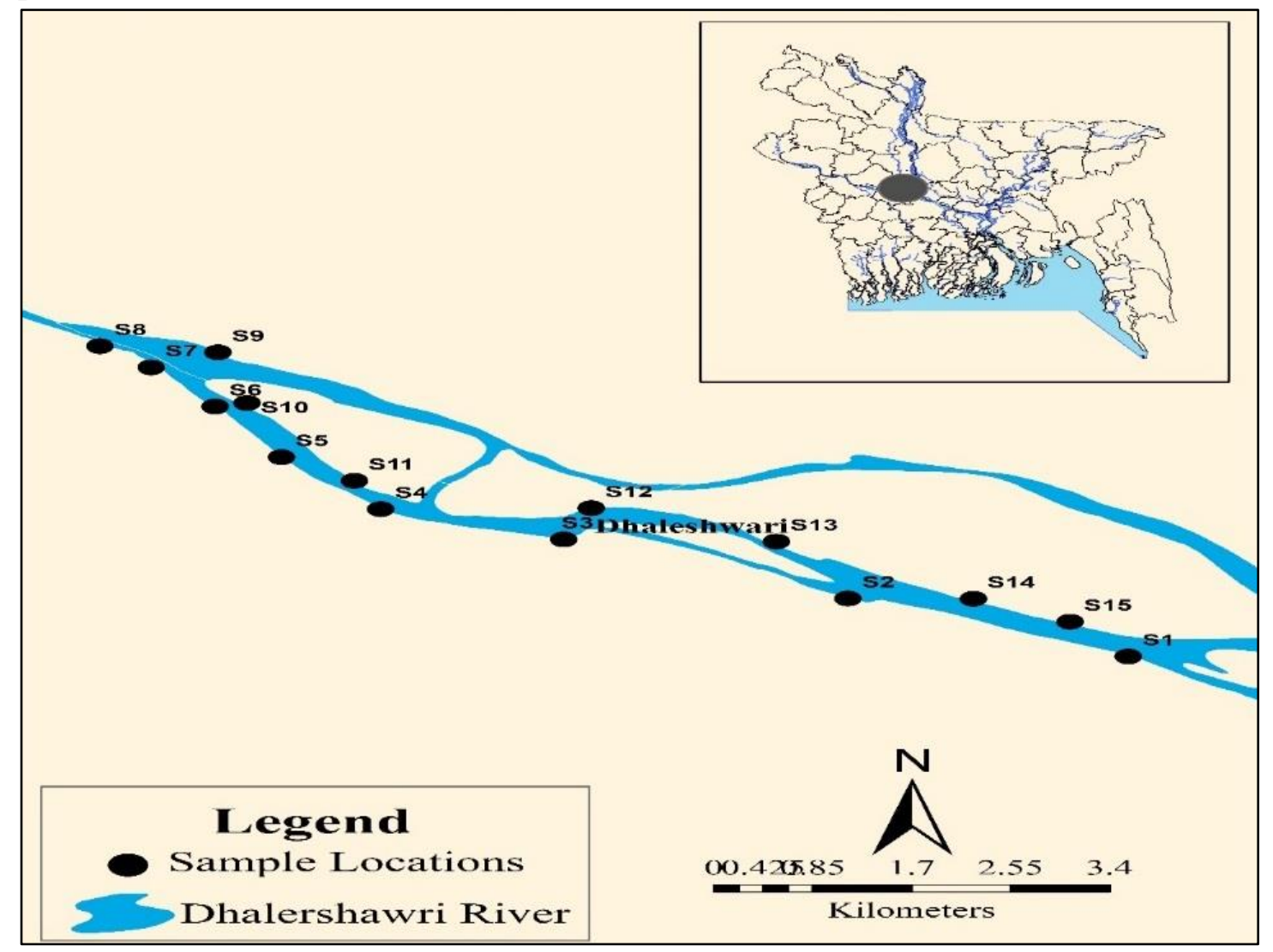

Fig 1. Study area and sampling sites. 


\section{Sediment Quality Assessment}

The physicochemical parameters and selected heavy metals in the river sediments were analyzed to measure the sediment quality, other parameters like Contamination Factor (CF), Degree of Contamination, Index of Geo-Accumulation ( $\mathrm{I}_{\text {geo }}$ ), Pollution load index (PLI) were calculated to figure out the level of the pollution in the river sediments.

\section{Physio-chemical Analysis of River Sediment}

Before $\mathrm{pH}$ and $\mathrm{EC}$ determination, the sediment sample was mixed with distilled water using shaking plate for 30 minutes. Then $\mathrm{pH}$ and $\mathrm{EC}$ were determined by a portable multiparameter meter (Model: Sense Ion, 156; HACH, USA). The Organic Matter (OM) content by sediment sample was assessed by the wet oxidation method of Walkley and Black (1934).

\section{Estimation of Heavy Metals in Sediment}

Heavy metals were analyzed using the Flame Atomic Spectrophotometer (FAAS) (APHA, 1998). Strong acid mixtures were used to examining heavy metals concentration (Baker and Amacher 1982). The sediment was separated using a large sieve to remove any large stones, pebbles, and organic matter. They were kept in acid-washed containers and oven-dried at 105 ${ }^{\circ} \mathrm{C}$ for $24 \mathrm{~h}$. Then The samples were fully grinded to the fine powder using an acid-washed pestle and mortar. After that $5 \mathrm{~g}$ of sediment was taken to an acid-washed beaker and $2.5 \mathrm{ml}$ $65 \%$ concentrated $\mathrm{HNO}_{3}$ and $7.5 \mathrm{ml} 37 \%$ concentrated $\mathrm{HClO}_{4}$ acid was added and the beaker was covered with a watch glass. $500 \mathrm{ml}$ of distilled water was added to each beaker when they were adequately cooled and placed into a temperature-controlled water bath $150{ }^{\circ} \mathrm{C}$ for $3 \mathrm{~h}$ (Hasan et al., 2015). Then the samples were cooled to room temperature and filtered by Whattman No.1 filter paper. $\mathrm{Cr}, \mathrm{Cd}, \mathrm{Cu}, \mathrm{Zn}$ and $\mathrm{Pb}$ concentration was performed by Shimadzu Atomic Absorption Spectroscopy (AA-7000) after calibrating with the chemical standard solution.

\section{Contamination Factor $(\mathrm{CF})$}

The contamination factor (CF) is used to determine the pollution load of the sediments (Manoj et al., 2012) by dividing each metal's concentration by its background value (Varol 2011). The formula is (Hakanson 1980).

$$
\mathrm{CF}=\frac{\text { Measured metal concentration }}{\text { Background concentration of the same metal }}
$$

In the present study, world surface rock average was used as background concentration (Martin and Meybeck 1979). (Table 1) shows the Index classification of sediment quality. The highest number shows that the metal concentration is 100 times greater than what would be predicted in the crust.

\section{Degree of Contamination}

The degree of contamination was calculated as the sum of all contamination factors (Ahdy and Khaled 2009). 'Degree of contamination' $C_{d}$ is used as a diagnostic tool for pollution control:

$$
C d=\sum_{i=1}^{i=n} C F
$$


The $\mathrm{C}_{\mathrm{d}}$ is the degree of overall contamination in surface layers in a particular core or sampling site (Hakanson 1980).

\section{Index of Geo-Accumulation ( $\left.I_{g e o}\right)$}

The Geo-accumulation index ( $\mathrm{Igeo}_{\mathrm{ge}}$ ) values were measured by Müller (1981) which is$\mathrm{Igeo}_{\mathrm{g}}=\log _{2}[\mathrm{Cn} /(1.5 \times \mathrm{Bn})]$

Where, $\mathrm{Cn}$ is the concentration of element $\mathrm{n}$ in the sediment and $\mathrm{Bn}$ is the geochemical context for the element $\mathrm{n}$ which is either measured in pre-civilization sediments of the area or driven from the literature (average shale value described by Turekian and Wedepohl1961). Based on $\mathrm{I}_{\text {geo }}$, sediments can be classified into seven classes (Table 1) (Legorburu et al., 2013).

\section{Pollution Load Index (PLI)}

The pollution load index (PLI) defines the quantity of an element in the environment (Tomlinson et al.,1980). The PLI of a single site is the $n$-th root of $n$ number of multiplied together contamination factor $(\mathrm{CF})$ values.

$\mathrm{PLI}=\left(\mathrm{CF}_{1} \times \mathrm{CF}_{2} \times \mathrm{CF}_{3} \times \ldots \ldots \ldots \times \mathrm{CF}_{\mathrm{n}}\right)^{1 / \mathrm{n}}$

PLI=zero, indicates perfection, PLI=1, indicates the presence of pollutant baseline levels only, and PLI>1, indicates progressive site quality degradation (Tomlison et al., 1980).

Table 1. Index classification of sediment quality (Müller 1981)

\begin{tabular}{lll}
\hline I-geo values & & \\
Müller (1981) & Class & Sediment quality \\
\hline$\leq 0$ & 0 & Unpolluted \\
$0-1$ & 1 & Unpolluted to moderately polluted \\
$1-2$ & 2 & Moderately polluted \\
$2-3$ & 3 & Moderately to strongly polluted \\
$3-4$ & 4 & Strongly polluted \\
$4-5$ & 5 & Strongly to extremely polluted \\
$\geq 6$ & 6 & Extremely polluted \\
CF values & & \\
Hakanson $(1980)$ & Class & Sediment quality \\
$\mathrm{CF}<1$ & 1 & Low CF \\
$1 \leq \mathrm{CF}<3$ & 2 & Moderate CF \\
$3 \leq \mathrm{CF}<6$ & 3 & Considerable CF \\
$\mathrm{CF} \geq 6$ & 4 & Very high CF \\
\hline
\end{tabular}

\section{Results and discussion}

Physicochemical Characteristics of Sediments of the Dhaleswari River

The experimental data on physicochemical parameters are presented in table 2. The level of $\mathrm{pH}$, Electric Conductivity (EC) and Organic Matter (OM) of Dhaleswari river sediment were found within 3.21-7.89, 359-1329 $\mu \mathrm{S} \mathrm{cm}^{-1}$ and $0.23-5.92 \%$ with mean values of 5.956, 662.533 $\mu \mathrm{S} \mathrm{cm}-1$ and $2.011 \%$ respectively (Table 2). According to DoE $1997 \mathrm{pH}$ and EC range was 
found from the Dhaleswari river was not within acceptable limits. $\mathrm{pH}$ is an important physicochemical parameter that indicates the acidic, basic, and neutral condition. It has an impact on the river ecosystem. Ahsan et al. (2018) found the $\mathrm{pH}$ of the Dhaleswari river water within 7.29-8.12. But from this study $\mathrm{pH}$ range of the river sediment was found in acidic condition. Hasan et al., found acidic to alkaline condition of the Meghna river sediment (Hasan et al.,2015). $\mathrm{pH}$ has significant influence on the adsorption, migration, and transformation of metals. Acidic and alkaline condition of the river might be caused by the domestic, industrial wastewater discharge and sometime by accidental release of chemical in river water (Yanhao, 2018). Organic matter of sediments can affect heavy metal accumulation (Suthar et al., 2009; Mohiuddin et al., 2010; Manoj et al., 2012). Electroconductivity is the measure of the ions. In some areas, the occurrence of high electric conductivity in river sediment was found. Tannery industries use vast quantities of chemicals such as lime, Salts, vegetable tannins, and color to process the leather which might increase the electroconductivity of the river sediment (Cooman et al., 2003).

Table 2. Physicochemical parameters of the Dhaleswari river sediment

\begin{tabular}{llll}
\hline Sample No. & $\mathrm{pH}$ & $\mathrm{EC}\left(\mu \mathrm{S} \mathrm{cm}^{-1}\right)$ & OM $(\%)$ \\
\hline S-1 & 6.89 & 366 & 1.51 \\
S-2 & 7.75 & 392 & 0.71 \\
S-3 & 7.25 & 359 & 5.92 \\
S-4 & 6.98 & 482 & 1.64 \\
S-5 & 7.89 & 697 & 0.23 \\
S-6 & 7.65 & 684 & 0.35 \\
S-7 & 4.56 & 1329 & 1.91 \\
S-8 & 6.65 & 681 & 5.72 \\
S-9 & 6.76 & 439 & 2.65 \\
S-10 & 6.70 & 491 & 1.29 \\
S-11 & 4.52 & 685 & 0.67 \\
S-12 & 3.56 & 558 & 4.52 \\
S-13 & 5.38 & 588 & 0.62 \\
S-14 & 3.59 & 1296 & 1.64 \\
S-15 & 3.21 & 891 & 0.79 \\
\hline Range & $3.21-7.89$ & $359-1329$ & $0.23-5.92$ \\
Mean & 5.956 & 662.533 & 2.011 \\
SD & 1.655 & 302.592 & 1.883 \\
DoE Standard 1997 & $6.5-8.5$ & 350 & No data
\end{tabular}

\section{Heavy Metals in Sediments}

Table 3 provides the results of metal concentrations of Dhaleswari river sediment samples and Sediment Quality Guidelines (SQG) limits. A decreasing order of $\mathrm{Zn}>\mathrm{Cu}>\mathrm{Cr}>\mathrm{Pb}>\mathrm{Cd}$ was observed in the sediment with the mean concentration of the analyzed heavy metal. The ranges of metal concentration were Cr: $31.49-65.8 \mathrm{mg} \mathrm{kg}^{-1}$ (mean 43.16), Cd: $0.2-0.8 \mathrm{mg} \mathrm{kg}^{-1}$ (mean 
0.37), Cu: 36-65.4 mg kg-1 (mean 48.89), Zn: 93.5-190.1 $\mathrm{mg} \mathrm{kg}^{-1}$ (mean 131.19), Pb: 28.3-38.4 $\mathrm{mg} \mathrm{kg}^{-1}$ (mean 33.23). The mean concentration of $\mathrm{Pb}$ and $\mathrm{Cd}$ of the sediment were found lower, but $\mathrm{Cr}, \mathrm{Cu}$ and $\mathrm{Zn}$ were exceeded WHO (2004) and USEPA (1989) Sediment Quality Guideline (SQG).

Table 3. Heavy metal concentration $\left(\mathrm{mg} \mathrm{kg}^{-1}\right)$ in the Dhaleswari river sediment

\begin{tabular}{llllll}
\hline Sample No. & $\mathrm{Cr}$ & $\mathrm{Cd}$ & $\mathrm{Cu}$ & $\mathrm{Zn}$ & $\mathrm{Pb}$ \\
\hline S-1 & 39.56 & 0.2 & 65.4 & 129.6 & 38.4 \\
S-2 & 38.16 & 0.2 & 61 & 93.5 & 29 \\
S-3 & 33.5 & 0.6 & 45.36 & 94.6 & 32.5 \\
S-4 & 36 & 0.4 & 58 & 119.6 & 36.64 \\
S-5 & 45.31 & 0 & 46.3 & 178 & 32 \\
S-6 & 65.8 & 0.5 & 46.7 & 169.3 & 33.28 \\
S-7 & 61.29 & 0.3 & 36 & 123.8 & 36.2 \\
S-8 & 58.75 & 0.3 & 36 & 182.56 & 36.4 \\
S-9 & 32 & 0.4 & 45.3 & 190.1 & 34.4 \\
S-10 & 33.25 & 0.2 & 49.5 & 98.6 & 35.5 \\
S-11 & 35 & 0.8 & 57.39 & 110.4 & 30.4 \\
S-12 & 62.25 & 0.7 & 52.21 & 125.5 & 28.3 \\
S-13 & 37 & 0.2 & 45.1 & 118 & 33.59 \\
S-14 & 31.49 & 0.2 & 42.69 & 113.8 & 32.4 \\
S-15 & 38.1 & 0.5 & 46.4 & 120.5 & 29.56 \\
\hline Max & 65.8 & 0.8 & 65.4 & 190.1 & 38.4 \\
Min & 31.49 & 0 & 36 & 93.5 & 28.3 \\
Mean & 43.16 & 0.37 & 48.89 & 131.19 & 33.23 \\
WHO (2004) SQG & 25.00 & 6.00 & 25.00 & 123.00 & NA \\
USEPA (1999) SQG & 25.00 & 0.60 & 16.00 & 110.00 & 40.00 \\
TRV & 81 & 1.2 & 34 & 150 & 46.7 \\
\hline SD-Standard Deviati & SQG-Sedim & (25.5 \\
\hline
\end{tabular}

SD- Standard Deviation, SQG-Sediment Quality Guideline, NA- Not Available, TRV-

Toxicity Reference Value

Concentration of Heavy metal

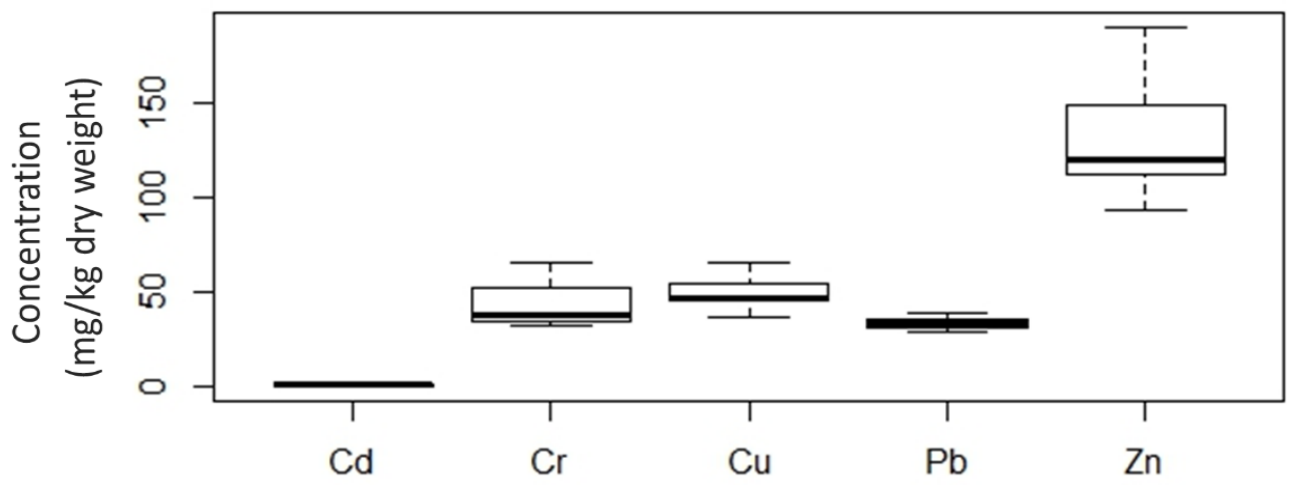

Fig. 2 Box plot representation of Concentration of Heavy metal 
The box plot representation of heavy metal concentration of Dhaleswari river are shown in (Fig. 2). Pearson's correlation coefficient matrix among the selected heavy metals of Dhaleswari river sediment is presented in Table 4. There is no significant correlation has been found. Hasan et al. (2016) showed that no significant correlation with each other in sediments that could be indication of separate source input or sources of pollution. Where highly significant positive correlations between heavy metals indicate the possibility of common and anthropogenic sources of origins (Armah et al., 2010).

Table 4. Pearson's Correlation coefficient

\begin{tabular}{llllll}
\hline & $\mathbf{C r}$ & $\mathbf{C d}$ & $\mathbf{C u}$ & $\mathbf{Z n}$ & $\mathbf{P b}$ \\
\hline $\mathbf{C r}$ & 1 & & & & \\
$\mathbf{C d}$ & 0.14 & 1 & & & \\
$\mathbf{C u}$ & -0.35 & 0.12 & 1 & & \\
$\mathbf{Z n}$ & 0.42 & -0.18 & -0.38 & 1 & \\
$\mathbf{P b}$ & 0.01 & -0.41 & -0.11 & 0.26 & 1 \\
\hline
\end{tabular}

*. Correlation is significant at the 0.05 level (2-tailed)

\section{Evaluation of Heavy Metals Pollution}

The heavy metal pollution of Dhaleswari river sediments were compared with the sediment quality guideline of United States EPA (1989). According to sediment quality guideline, for $\mathrm{Cr}, \mathrm{Cu}, \mathrm{Zn}$ sediment in all locations of Dhaleswari river have been found moderately polluted. location S-1, S-2, S-4, S-8, S-11, S-12 for Cu was heavily polluted. In case of Pb and Cd, all locations was not polluted except S-11 and S-12 location for Cd was heavily polluted.

Based on the sediment Toxicity Reference Value (TRV) of USEPA (1989) the river sediment pollution was calculated by comparison (Fig. 3). It is a toxicological index parameter commonly used for risk assessment. The study shows that only $\mathrm{Cu}$ (as shown in Fig. 3b) exceeds the TRV value. For Zn, except S-5, S-6, S-8 and S-9, the value of all other locations were below TRV (Fig. 3d) and Cd, Cr, and Pb were found bellow TRV (Fig. 3a, 3c, 3e). 

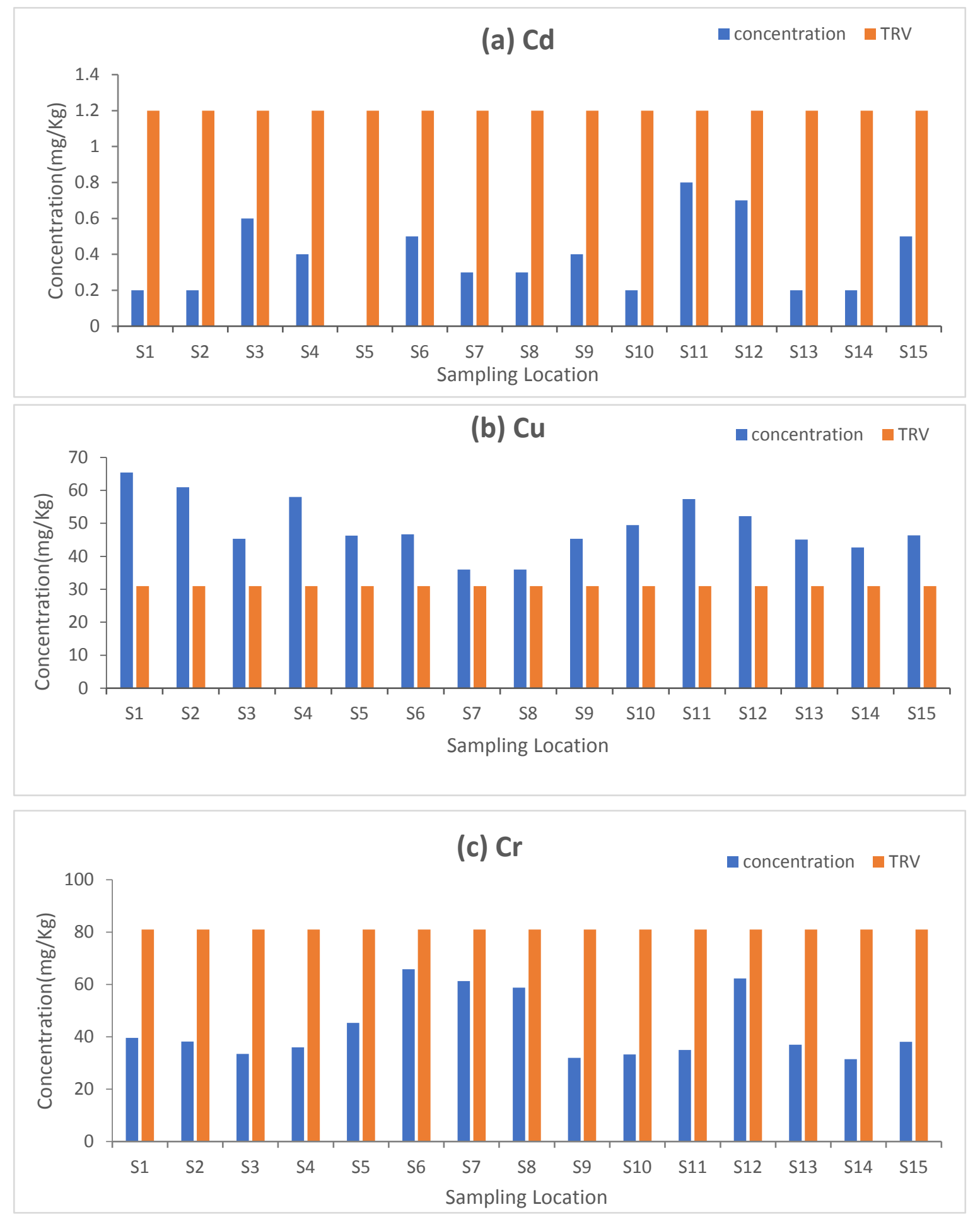


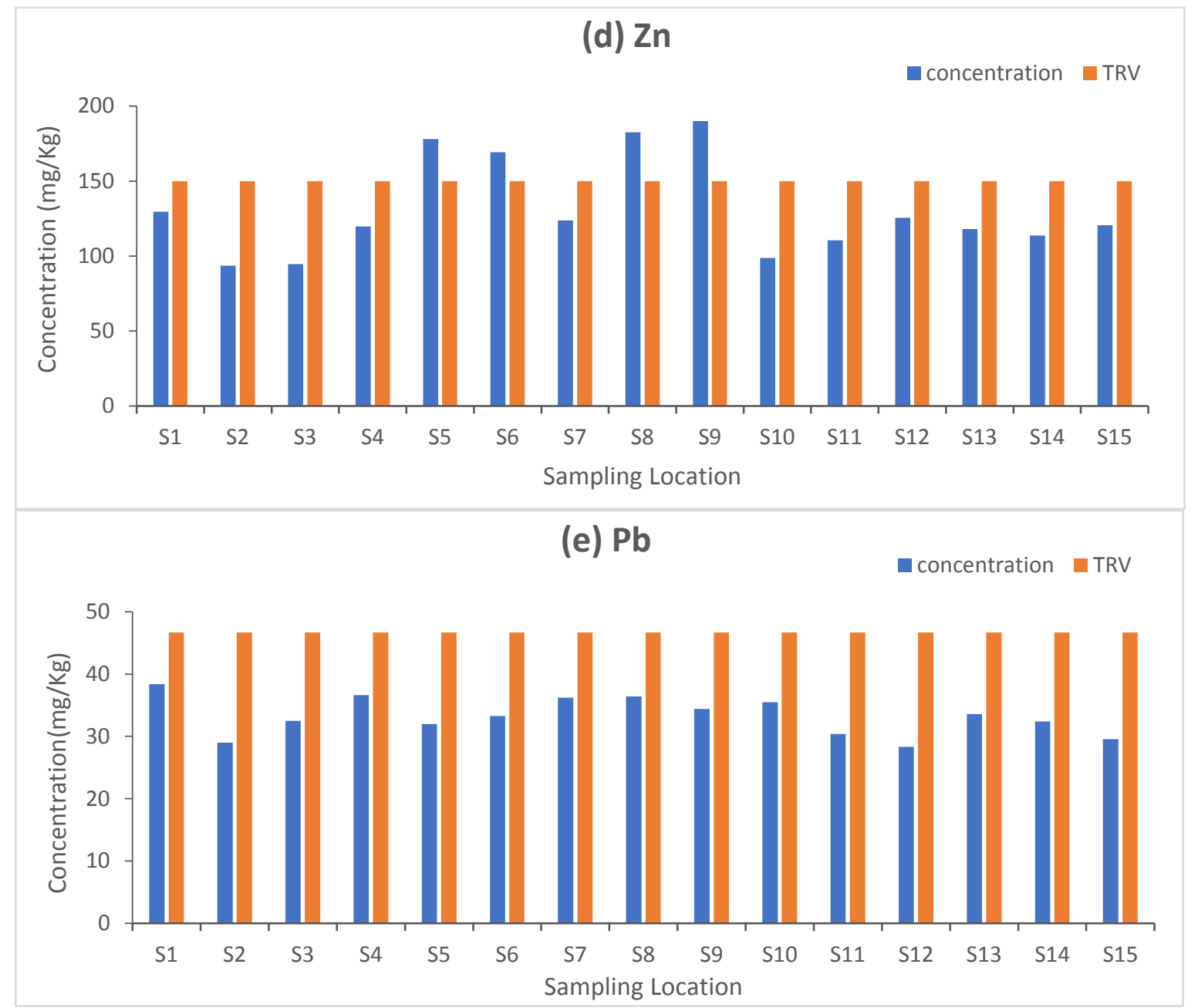

Fig. 3 (a-e). Toxic metal concentration $\left(\mathrm{mg} \mathrm{kg}^{-1}\right)$ of Dhaleswari river sediment compared with TRV.

The measured values of Igeo of Dhaleswari river sediments of 15 locations were presented in Fig. 4. The Igeo values suggest that the sampling points S-3, S-6, S-11,S-12 and S-15 were unpolluted to moderately polluted by Cadmium (Cd). Sampling sites S-5, S-6, S-8 and S-9 was found unpolluted to moderately polluted by Zinc ( $\mathrm{Zn})$. In case of lead $(\mathrm{Pb})$, all locations were found unpolluted to moderately polluted except S-2, S-12 and S15 according to the classification of the geo-accumulation index. The major risk factors in the study area are $\mathrm{Cd}, \mathrm{Zn}$ and $\mathrm{Pb}$. 


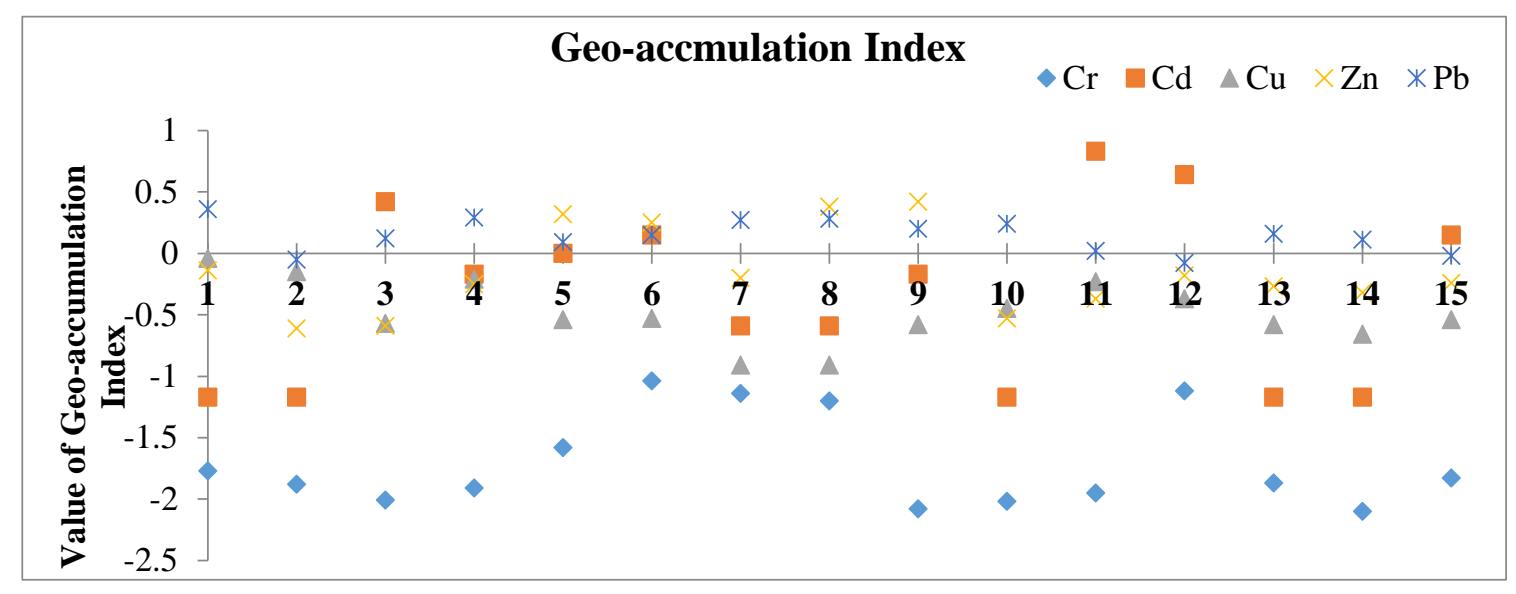

Fig. 4 Variation of Geo-accumulation Index (Igeo) values of heavy metals of the Dhaleswari river sediments.

Table 5. Contamination Factor, Contamination Degree and Pollution Load Index values.

\begin{tabular}{|c|c|c|c|c|c|c|c|}
\hline \multirow[b]{2}{*}{$\begin{array}{l}\text { Sampling } \\
\text { Sites }\end{array}$} & \multicolumn{5}{|c|}{ Contamination factor (CF) } & \multirow{2}{*}{$\begin{array}{l}\text { Degree of } \\
\text { Contamination } \\
\text { (CD) }\end{array}$} & \multirow{2}{*}{$\begin{array}{l}\text { Pollution } \\
\text { Load Index } \\
\text { (PLI) }\end{array}$} \\
\hline & $\mathrm{Cr}$ & $\mathrm{Cd}$ & $\mathrm{Cu}$ & $\mathrm{Zn}$ & $\mathrm{Pb}$ & & \\
\hline S-1 & 0.440 & 0.667 & 1.453 & 1.364 & 1.920 & 5.844 & 1.022 \\
\hline $\mathrm{S}-2$ & 0.424 & 0.667 & 1.356 & 0.984 & 1.450 & 4.881 & 0.886 \\
\hline S-3 & 0.372 & 2.000 & 1.008 & 0.996 & 1.625 & 6.001 & 1.036 \\
\hline S-4 & 0.400 & 1.333 & 1.289 & 1.259 & 1.832 & 6.113 & 1.097 \\
\hline S-5 & 0.503 & 0 & 1.029 & 1.874 & 1.600 & 5.006 & 0 \\
\hline S-6 & 0.731 & 1.667 & 1.038 & 1.782 & 1.664 & 6.882 & 1.303 \\
\hline S-7 & 0.681 & 1.000 & 0.800 & 1.303 & 1.810 & 5.594 & 1.051 \\
\hline S-8 & 0.652 & 1.000 & 1.244 & 1.922 & 1.820 & 6.638 & 1.232 \\
\hline S-9 & 0.356 & 1.333 & 1.007 & 2.001 & 1.720 & 6.417 & 1.105 \\
\hline S-10 & 0.369 & 0.667 & 1.100 & 1.038 & 1.775 & 4.949 & 0.870 \\
\hline S-11 & 0.388 & 2.667 & 1.275 & 1.162 & 1.520 & 7.012 & 1.184 \\
\hline S-12 & 0.691 & 2.333 & 1.160 & 1.321 & 1.415 & 6.920 & 1.284 \\
\hline S-13 & 0.411 & 0.667 & 1.002 & 1.242 & 1.680 & 5.002 & 0.895 \\
\hline S-14 & 0.349 & 0.667 & 0.949 & 1.198 & 1.620 & 4.783 & 0.844 \\
\hline S-15 & 0.423 & 1.667 & 1.031 & 1.268 & 1.478 & 5.867 & 1.064 \\
\hline Mean & 0.479 & 1.222 & 1.116 & 1.381 & 1.662 & 5.861 & 1.084 \\
\hline SD & 0.137 & 0.731 & 0.175 & 0.343 & 0.153 & 0.801 & 0.247 \\
\hline
\end{tabular}

(*SD-Standard Deviation)

From table 5 the calculated value of contamination factor and degree of contamination indicates that most of the sampling site was moderately contaminated. $\mathrm{Cr}$ in all sampling site was found low contamination $(\mathrm{CF}<1)$; Cd in all locations except S-1, S-2, S-5, S-10, S-13, and S-14 was found moderate contamination; Cu in all locations except S-7 and S-14 were found moderate contamination; Zn in all locations except S-2 and S-3 were found moderate contamination; $\mathrm{Pb}$ in all locations were found moderate contamination $(1 \leq \mathrm{CF}<3)$. The mean values of the $\mathrm{CF}$ were found $\mathrm{Cr}: 0.479$ (low contamination); $\mathrm{Cd}: 1.222$ (moderate contamination); 
Cu:1.116 (moderate contamination); $\mathrm{Zn}: 1.381$ (moderate contamination); and $\mathrm{Pb}: 1.662$ (moderate contamination). Sediments are enriched for metals based on mean values of $\mathrm{CF}: \mathrm{Pb}>\mathrm{Zn}>\mathrm{Cd}>\mathrm{Cu}>\mathrm{Cr}$.

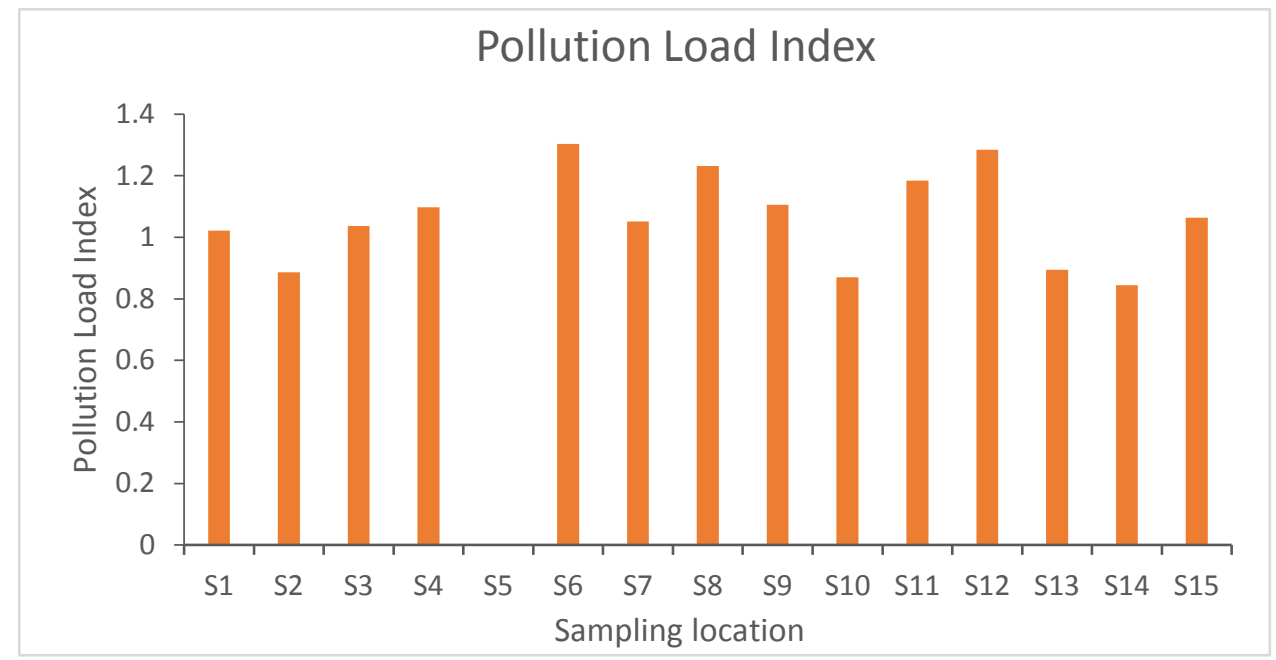

Fig. 5 Pollution Load Index of heavy metal.

PLI values of all sampling points are shown in Fig. 5. PLI values varied between 0 and 1.303 . On the S-6 sampling site, the highest PLI value was found. The PLI values were found higher than 1 at most sampling sites, suggesting a baseline level of pollution. where PLI value lower than 1 that indicating no pollution (Hasan et al., 2015)

Table 6. Heavy metal concentration ( $\mathrm{mg} \mathrm{kg}^{-1}$ dry weights) of the Dhaleswari river sediments and some other rivers of Bangladesh

\begin{tabular}{lllllll}
\hline Rivers & $\mathrm{Pb}$ & $\mathrm{Cd}$ & $\mathrm{Cr}$ & $\mathrm{Cu}$ & $\mathrm{Zn}$ & References \\
\hline Dhaleswari & 33.23 & 0.37 & 43.16 & 48.89 & 131.19 & Present study \\
Buriganga & 69.75 & 3.33 & 177.5 & 27.85 & - & Ahmed et al. 2010 \\
Bangshi & 59.99 & 0.61 & 98.1 & - & 117.15 & Rahman et al. 2014 \\
Karnofuly & 43.69 & 2.01 & 20.3 & - & - & Ali et al. 2016 \\
Meghna & 9.47 & 0.23 & 31.74 & - & 79.02 & Hassan et al. 2015 \\
Shitalakhya & 28.36 & 5.01 & 63.22 & - & 75 & Islam et al. 2014 \\
Turag & 1.64 & 1.4 & 0.44 & 1.576 & 108 & Banu et al. 2013 \\
\hline
\end{tabular}

Tables 6 shows the comparison of the concentration of heavy metals between Dhaleswari river and other rivers in Bangladesh to understand the present condition of the heavy metal of the Dhaleswari river sediment. The present study shows the high concentration of $\mathrm{Zn}, \mathrm{Cu}$ and $\mathrm{Cd}$ in the sampled sediment. Rahman et al. (2014) found high concentration of $\mathrm{Pb}, \mathrm{Cr}$ and $\mathrm{Zn}$ in Bangshi river sediment and water. It was described that the main source of the $\mathrm{Pb}$ is not industrial, motor vehicle is responsible for the high level of lead contamination. Ahmed et al. recommend high level of heavy metal pollution of Buriganga river might affect the fish community which is unsafe for human health (Ahmed et al., 2010). It was found that heavy metals are not 
biodegradable and have a major environmental impact. When heavy metals are consumed or inhaled into our bodies, they bioaccumulate in our system and cause biological and physiological complications. Such as, zinc is accumulated mostly in the liver and then distributed throughout the whole body. Major storage sites for zinc are the liver, bone, pancreas, kidney, and muscles (Briffa et al., 2012). Cadmium cause cytotoxicity and affect the immune system even expose at low concentration (Das et al., 2018). Chronic exposure to lead contributes to increased blood pressure. Critical hormonal and neuronal systems are also affected by lead (Briffa et al., 2012). Lead has the potential noncarcinogenic risk for children (Qiao et al., 2011). The high content of chromium of this present study might be generated from the tannery effluent. Because the tannery industry uses the chrome tanning method which is threatening to the ecosystem (EPC, 1980). Chromium causes serious diseases like cancer and birth defects because of long-term exposure (WHO, 1996). Dhaleswari river sediment is also polluted and contaminated by heavy metal as other researchers have found the same condition in the other rivers of Bangladesh.

\section{Conclusion}

To the best of our knowledge, this is the first study that investigated the level of heavy metal pollution and accumulation behavior on the sediment of the Dhaleswari river. This study showed that the $\mathrm{Cr}, \mathrm{Zn}$ and $\mathrm{Cu}$ concentrations in the sediment of the Dhaleswari river are higher than the USEPA guidelines. $\mathrm{Cd}$ and Pb level found at all sampling sites was below the guideline level. Most of the sampling sites were unpolluted or moderately polluted, according to the geo-accumulation index (Igeo). Values of the Pollution Load Index (PLI) showed that most sampling sites have a baseline pollution level. All sampling sites had a moderate pollution, except for $\mathrm{Cr}$, according to the mean contamination factor $(\mathrm{CF})$. The status of Dhaleswari river sediments is unpolluted to moderately contaminated. The correlation coefficient matrix demonstrated no significant correlation among heavy metals in sediments that could be an indication of different input or sources of heavy metal pollution. So, it is important to monitor the pollution status of the river water and sediments regularly for understanding the sources, transportation, and fate of the hazardous heavy metals as well as for the proper environmental management.

\section{Conflict of interest}

The article is original and contains unpublished material. The authors have no conflict of interest in the development and publication of current research. 


\section{Author contribution statements}

Abdullah Al Mamun designed the study, performed the statistical analysis, managed the analyses of the study. Protima Sarker managed the literature searches, wrote the protocol and the first draft of the manuscript, and supervised the study. Mohammad Mahbub Kabir produced the map and checked the final proofread. Md. Shiblur Rahaman and Masahiro Maruo reviewed and revised the manuscript. All authors read and approved the final manuscript.

\section{Acknowledgment}

The authors are thankful to the Department of Environmental Science and Disaster Management of Noakhali Science and Technology University, Noakhali, Bangladesh and Bangladesh Council of Scientific and Industrial Research (BCSIR) Dhaka, Bangladesh for research assistance and sediment quality analysis.

\section{References}

Ahdy, H.H.H. and Khaled, A., 2009. Heavy metals contamination in sediments of the western part of Egyptian Mediterranean Sea. Australian Journal of Basic and Applied Sciences, 3(4), 3330-3336.

Ahmad, J.U. and Goni, M.A., 2010. Heavy metal contamination in water, soil, and vegetables of the industrial areas in Dhaka, Bangladesh. Environmental Monitoring and Assessment, 166, 347-357. https://doi.org/10.1007/s10661-009-1006-6

Ahmad, M.K., Islam, S., Rahman, S., Haque, M.R., Islam, M.M., 2010. Heavy Metals in Water, Sediment and Some Fishes of Buriganga River, Bangladesh. International Journal of Environmental Research, 4(2), 321-332. https://dx.doi.org/10.22059/ijer.2010.24

Ahsan, M.A., Siddique, M. A. B., Munni, M.A., Akbor, M. A., Akter, S. and Mia, M.Y., 2018. Analysis of Physicochemical Parameters, Anions and Major Heavy Metals of the Dhaleshwari River Water, Tangail, Bangladesh. American Journal of Environmental Protection, 7, 29-39. https://doi.org/10.11648/j.ajep.20180702.12

Alam, M.N., Elahi, F. and Didar-Ul-Alam, M., 2006. Risk and Water Quality Assessment overview of River Sitalakhya in Bangladesh, Academic Open Internet Journal, 19. http://www.acadjournal.com/2006/V19/Part2/P1/

Ali, M.M., Ali, M.L., Islam, M.S. and Rahman, M.Z., 2016. Preliminary assessment of heavy metals in water and sediment of Karnaphuli river, Bangladesh. Environmental Nanotechnology Monitoring and Management 5, 27-35. https://doi.org/10.1016/j.enmm.2016.01.002 
APHA, 1998. Standard methods for the examination of water and wastewater. American Public Health Association, Washington DC, USA.

Armah, F.A., Obiri, S., Yawson, D.O., Onumah E.E. and Yengoh, G.T., 2010. Anthropogenic sources and environmentally relevant concentrations of heavy metals in surface water of a mining district in Ghana: A multivariate statistical approach. Journal of Environmental Science and Health, Part A, 45, 1804 1813. https://doi.org/10.1080/10934529.2010.513296

Baker, D.E. and Amacher, M.C., 1982. Nickel, copper, zinc and cadmium. In: Page, et al. (ends). Methods of soil analysis, part 2, Chemical and Microbiological Properties. 2nd ed. American Society of Agronomy, 323-333. https://doi.org/10.2134/agronmonogr9.2.2ed.c19

Banu, Z., Chowdhury, M.S.A., Hossain, M.D. and Nakagami, K., 2013. Contamination and ecological risk assessment of heavy metal in the sediment of Turag river, Bangladesh: An index analysis approach. Journal of Water Resource and Protection, 5, 239-248. https://doi.org/10.4236/jwarp.2013.52024

Barakat, A., Baghdadi, M. E., Rais, J. and Nadem, S., 2012. Assessment of heavy metal in surface sediments of Day river at Beni-Mellal Region, Morocco. Research Journal of Environmental and Earth Sciences 4,797-806.

Briffa, J., Sinagra, E. and Blundell, R., 2020. Heavy metal pollution in the environment and their toxicological effects on humans. Heliyon, 6, e04691. https://doi.org/10.1016/j.heliyon.2020.e04691

Cooman, K., Gajardo, M., Nieto, J., Bornhardt, C. and Vidal, G., 2003. Tannery wastewater characterization and toxicity effects on Daphnia spp., Environmental Toxicology, 18, 45-51. https://doi.org/10.1002/tox.10094

Das, K.K., Reddy, R.C., Bagoji, I.B., Das, S., Bagali, S., Mullur, L., Khodnapur, J.P. and Biradar, M.S., 2018. Primary concept of nickel toxicity-An overview. Journal of Basic and Clinical Physiology and Pharmacology, 30, 141-152. https://doi.org/10.1515/jbcpp-2017-0171

DoE, 1997. Environment conservation rules, E.C.R., schedule 3, standards for water. Department of Environment of Bangladesh.

EPC, 1980. A resume of environment pollution control in Bangladesh

Hakanson, L. 1980. An ecological risk index for aquatic pollution control a sedimentological approach. Water Research, 14, 975-1001. https://doi.org/10.1016/0043-1354(80)90143-8

Hassan, M., Rahman, M.A.T.M., Saha, B. and Kadir, A., 2015. Status of Heavy Metals in Water and Sediment of the Meghna River, Status of Heavy Metals in Water and Sediment of the Meghna River, Bangladesh. American Journal of Environmental Science, 11, 427-439. https://doi.org/10.3844/ajessp.2015.427.439 
Hossain, M.D., Rahman, M.M., Chandra, J.B., Shammi, M, Uddin, M.K., 2012. Present status of water quality of the Bangshi River, Savar, Dhaka, Bangladesh. Bangladesh Journal of Environmental Research, 10, 17-30.

Islam, M.M., Rahman, S.L., Ahmed, S.U. and Haque, M.K.I., 2014. Biochemical characteristics and accumulation of heavy metals in fishes, water and sediments of the river Burigonga and Shitalakhya of Bangladesh. Journal of Asian Scientific Research, 4, 270-279.

Islam, M.M., Karim, M.R., Zheng, X. and Li, X., 2018. Heavy Metal and Metalloid Pollution of Soil, Water and Foods in Bangladesh: A Critical Review. International Journal of Environmental Research and Public Health, 15, 2825. https://doi.org/10.3390/ijerph15122825

Islam, M.S., Ahmed, M.K., Habibullah-Al-Mamun, M., Raknuzzaman, M., Ali, M.M. and Eaton, D.W., 2016. Health risk assessment due to heavy metal exposure from commonly consumed fish and vegetables. Environment Systems and Decisions, 36, 1-13. https://doi.org/10.1007/s10669-016-95927

Islam, M.S., Meghla, N.T., Suravi, Mamun, S.A., and Islam, M., 2012. Status of water quality in the Dhaleshwari River and its effect on aquatic organism, Journal of Environmental Science and Water Resources, 1 (9), 192-201.

Islam, M.S., Ahmed, M.K., Habibullah-Al-Mamun, M., and Hoque, M.F., 2015. Preliminary assessment of heavy metal contamination in surface sediments from a river in Bangladesh. Environmental Earth Science, 73, 1837-1848. https://doi.org/10.1007/s12665-014-3538-5

Jumbe, A.S. and Nandini, N., 2009. Heavy metals analysis and sediment quality values in urban lakes. American Journal of Environmental Science, 5, 678-687. https://doi.org/10.3844/ajessp.2009.678.687

Kabir, K.M.H., Uddin, M.K. and Khabir, A., 2010. Physicochemical Characteristics of Shitalakhya River water, Their Impacts and Possible Mitigation. Journal of Environmental Science and Natural resources, 3, 101-105.

Legorburu, I., Rodríguez, J.G., Borja, Á., Menchaca, I., Solaun, O., Valencia, V., Galparsoro, I., and Larreta, J., 2013. Source characterization and spatio-temporal evolution of the metal pollution in the sediments of the Basque estuaries (Bay of Biscay). Marine Pollution Bulletin, 66, 25-38. https://doi.org/10.1016/j.marpolbul.2012.11.016

Lee, C.L., Li, X.D., Zhang, G., Li, J., Ding, A.J. and Wang, T., 2007. Heavy metals and Pb isotopic composition of aerosols in urban and suburban areas of Hong Kong and Guangzhou, South China Evidence of the long-range transport of air contaminants. Atmospheric Environment, 41, 432-447. https://doi.org/10.1016/j.atmosenv.2006.07.035 
Manoj, K., Kumar, B. and Padhy, P.K., 2012. Characterization of metals in water and sediments of Subarnarekha river along the projects' sites in Lower Basin, India. Universal Journal of Environmental Research and Technology, 2, 402-410.

Martin, J.M. and Meybeck, M., 1979. Elemental mass balance of materials carried by major world rivers. Marine Chemistry, 7, 173-206. https://doi.org/10.1016/0304-4203(79)90039-2

Marrugo-Negrete, J., Pinedo-Hernández, J., and Díez, S., 2017. Assessment of heavy metal pollution, spatial distribution, and origin in agricultural soils along the Sinú River Basin, Colombia. Environmental Research, 154, 380-388. https://doi.org/10.1016/j.envres.2017.01.021

Miller, C.V., Foster, G.D. and Majedi, B.F., 2003. Base flow and storm flow metal fluxes from two small agricultural catchments in the coastal plain of Chesapeake Bay Basin, United States. Applied Geochemistry, 18, 483-501. https://doi.org/10.1016/S0883-2927(02)00103-8

Mohanta, L.C., Niloy, M.N.H., Chowdhury, G.W., Islam, D. and Lipy, E. P., 2019. Heavy Metals in Water, Sediment and Three Fish Species of Dhaleshwari River, Savar, Bangladesh, Bangladesh Journal of Zoology, 47, 263-272. https://doi.org/10.3329/bjz.v47i2.44337

Mohiuddin, K.M., Zakir, H.M., Otomo, K., Sharmin, S. and Shikazono, N., 2010. Geochemical distribution of trace metal pollutants in water and sediments of downstream of an urban river. International Journal of Environmental Science and Technology, 7, 17-28. https://doi.org/10.1007/BF03326113

Müller, G., 1981. The heavy metal pollution of the sediments of Neckars and its tributary, Chemiker Zeitung $105,157-164$.

Nguyen, T.T.H., Zhang, W., Li, Z., Li, J., Ge, C., Liu, J., Bai, X., Feng, H. and Yu, L., 2016. Assessment of heavy metal pollution in Red River surface sediments, Vietnam. Marine Pollution Bulletin, 113, 513519. https://doi.org/10.1016/j.marpolbul.2016.08.030

Paul, R. and Haq, A., 2010. Challenges of Water Quality Management: Case of Peripheral rivers in Dhaka Mega City, Presentation from the World Water Week in Stockholm.

Parvin, R., Sultana, A. and Zahid, M.A., 2014. Detection of Heavy Metals in Vegetables Cultivated in Different Locations in Chittagong, Bangladesh. IOSR Journal of Environmental Science, Toxicology and Food Technology, 8, 58-63.

Qiao, M., Cai, C., Huang, Y., Liu, Y., Lin, A. and Zheng, Y., 2011. Characterization of soil heavy metal contamination and potential health risk in metropolitan region of northern China. Environmental Monitoring and Assessment, 172, 353-365. https://doi.org/10.1007/s10661-010-1339-1

Rahaman, M.S., Akter, M., Rahman, M.M., Sikder, M.T., Hosokawa, T., Saito, T. and Kurasaki, M., 2020. Investigating the protective actions of D-pinitol against arsenic-induced toxicity in PC12 cells and the 
underlying mechanism. Environmental Toxicology and Pharmacology. 74:103302. https://doi.org/10.1016/j.etap.2019.103302.

Rahman, M.S, Saha, N. and Molla, A.H., 2014. Potential ecological risk assessment of heavy metal contamination in sediment and water body around Dhaka export processing zone, Bangladesh. Environmental Earth Science, 71, 2293-2308. https://doi.org/10.1007/s12665-013-2631-5

Real, K.H., Khanam, N., Mia, M.Y., and Nasreen, M., 2017. Assessment of Water Quality and Microbial Load of Dhaleshwari River Tangail, Bangladesh. Advances in Microbiology, 7, 523-533.

Suthar, S., Nema, A.K., Chabukdhara, M. and Gupta S.K., 2009. Assessment of metals in water and sediments of Hindon river, India: Impact of Industrial and Urban Discharges. Journal of Hazardous Material, 171, 1088-1095. https://doi.org/10.1016/j.jhazmat.2009.06.109

Taherdoost, H., 2016. Sampling Methods in Research Methodology; How to Choose a Sampling Technique for Research, SSRN Electronic Journal, 5(2), 18-27. http://dx.doi.org/10.2139/ssrn.3205035

Tomlinson, D.L., Wilson J.G., Harris, C.R. and Jeffney, D.W.,1980. Problems in the assessment of heavymetal levels in estuaries and the formation of a pollution index. Helgoland Marine Research, 33, 566-572. https://doi.org/10.1007/BF02414780

Turekian, K.K. and Wedepohl, K.H.,1961 Distribution of the elements in some major units of the earth's crust. Geological Society of America Bulletin., 72, 175-192. https://doi.org/10.1130/00167606(1961)72[175:DOTEIS]2.0.CO;2

USEPA, 1989. Sediment classification methods compendium. Draft Final Report, United States Environmental Protection Agency, Watershed Protection Division, USA.

USEPA, 1999. Screening level ecological risk assessment protocol for hazardous waste combustion facilities, Appendix E: Toxicity reference values. United States Environmental Protection Agency, Solid Waste and Emergency Response (5305W), EPA530-D-99-001A.

USEPA., 2001. Methods for Collection, Storage and Manipulation of Sediments for Chemical and Toxicological Analyses: Technical Manual. EPA 823-B-01-002. United States Environmental Protection Agency, Office of Water, Washington, DC.

Venugopal, T., Giridharan, L., and Jayaprakash, M., 2009. Characterization and risk assessment studies of bed sediments of river Adyar, an application of speciation study. International Journal of Environmental Research, 3, 581-598.

Varol, M., 2011. Assessment of heavy metal contamination in sediments of the Tigris river (Turkey) using pollution indices and multivariate statistical techniques. Journal of Hazardous Material,195, 355-364. https://doi.org/10.1016/j.jhazmat.2011.08.051 
Walkley, A. and Black, I.A., 1934. An examination of Degtjareff method for determining Soil organic matter and a proposed modification of the chromic acid titration method. Soil Science, 37, 29-37.

WHO, 2004. Guidelines for Drinking Water Quality. $3^{\text {rd }}$ ed., World Health Organization, Geneva. 335-459. ISBN 9241546387

WHO, 1996. Guidelines for drinking-water quality, $2^{\text {nd }}$ ed., World Health Organization, Geneva. 942 ISBN 9241544805

Yanhao, Z., Haohan, Z., Zhibin, Z., Chengying, L., Cuizhen, S., Wen, Z., Taha, M., 2018. pH Effect on Heavy Metal Release from a Polluted Sediment, Journal of Chemistry, 7, Article ID 7597640. https://doi.org/10.1155/2018/7597640

Zhao, G., Ye, S., Yuan, H., Ding, X., Wang, J. and Laws, E.A., 2018. Surface sediment prop-erties and heavy metal contamination assessment in river sediments of the Pearl River Delta, China. Marine Pollution Bulletin, 136, 300-308. https://doi.org/10.1016/j.marpolbul.2018.09.035 